The evaluation and utilization of a wide range of world material needs considerable knowledge of taxonomy and cytology as well as genetics. Further, the study of the evolution and adaptation of cultivated plants is a separate discipline in itself. It was with the object of surveying existing knowledge of the origin and distribution of cultivated plants in South Asia that the Indian Society of Genetics and Plant Breeding, in association with the United Nations Educational, Scientific and Cultural Organization, held a symposium on this subject in Delhi during January 12-15, 1951. The proceedings of the meeting have now been reported in full in the special "Symposium" number of the Indian Journal of Genetics and Plant Breeding (11, No. 1), which has been recently published. In addition to a large number of members of the Indian Society of Genetics and Plant Breeding, the symposium was attended by representatives of other scientific institutions in India and of Unesco, and by delegates from Ceylon, China, Malaya and Pakistan. Profs. E. Anderson, S. C. Harland and A. Müntzing were invited as "expert consultants".

Altogether, twenty-three papers were read, covering a wide range of crops, including rice, wheat, banana, mango, citrus, sugar-cane, millets, cotton and jute. Much new information was presented, and it was evident that the Asiatic countries are for the most part fully aware of the nature and complexity of modern methodology in plant breeding, though they are only occasionally well enough equipped to solve their special local problems.

The participants of the symposium made a series of recommendations for the betterment of plant breeding in South Asia. These emphasized that plant introductions should be made from areas having similar climatic and environmental conditions. The importance of new introductions of plants from Mexico, Peru and Guatemala was stressed. By means of appropriato national or international organizations, the plant resources of the whole area of South Asia should be surveyed, and plant breeding should be accompanied by fundamental work on cytogenetics and physiology in the various botanical research centres.

S. C. Harland

\section{PACIFIC SCIENCE ASSOCIATION}

$T$

HE Pacific Science Association, which was 1 founded in 1920 and has consistently sought to promote scientific progress in the Pacific, includes as integral parts of its organization the Pacific Science Council, a number of standing committees and the Pacific Science Congresses, of which the eighth is to be held in the Philippines in 1953. The secretariat of the Council has now issued a first report of the Association*, which describes in detail the organization of the Association and its constituent bodies, and its relations with the South Pacific Commission and with the Pacific Science Board of the United States National Research Council; the report also sketches the activities of the Association and its Congresses during the past thirty years as well as, more particularly, the activities of the secretariat during 1950.

Since the constitution and by-laws of the Association are included with the resolutions for research in

* Bernice P. Bishop Museum. Special Publication 41 : Report on the Pacific Science Association. Prepared by the Secreteriat of the Council, 1951.) the Pacific passed at the first seven Congresses and with particulars of the organizing committees and projects appointed for the eighth Congress in 1953, the report constitutes a unique reference handbook on research in this area. The resolutions of previous Congresses are arranged under geology, geodesy and geophysics, volcanology and seismology, meteorology, oceanography, zoology, entomology, botany, conservation, agriculture and soils, forestry, anthropology and social studies, and health and nutrition; they are cross-referenced and are preceded by short accounts indicating the general lines of work and progress made.

'The idea of the Pacific Science Association had its origins at meetings earlier than the Pan-Pacific Scientific Congress at Honolulu in August 1920 - for example, the Australian meeting of the British Association in 1914, the symposium on Pacific Exploration at the 1916 meeting of the United States National Academy of Sciences, and the conference on international relations at the science-centennial anniversary of the University of California in 1918and the Pacific Scientific Institution at Hawaii was incorporated in 1907. The Honolulu Congress included sessions on anthropology, biological sciences, geography, geology, seismology and volcanology, and it was resolved that similar conferences should be held at intervals of not more than three years. At the second congress in Melbourne and Sydney in 1923, when the attendance of 101 from nine territories increased to $\mathbf{1 , 3 8 9}$ from twenty-one territories, and other sections were added, further steps were taken towards a permanent organization with its own central scientific bureau or secretariat, and the present constitution and by-laws were adopted at the third Congress in Tokyo in 1926, when the prefix "Pan" was dropped from the title.

The constitution provides for a Council of ten to fifteen members and a number of standing committees to study the more important problems of common interest and to report on their work at the succeeding congresses. There are at present seventeen such committees; but a permanent secretariat was not established until the seventh Congress, in New Zealand in 1949, and in this Congress the United Nations Educational, Scientific and Cultural Organization played an important part, contributing a subvention of 20 million dollars to enable scientific workers from war-devastated countries in Europe and Asia to be invited. Members from Trust Territories in the Pacific were also represented. Other Congresses were held at Java in 1929, in Vancouver and Victoria, British Columbia, 1933, and in California during July-August 1939.

The seventh Congress, originally scheduled for 1943 in the Philippines, was postponed until 1949, and at this meeting Honolulu was selected as the international headquarters, the secretariat being officially established there in the Bernice P. Bishop Museum on March 20, 1950. The secretariat is assembling a file on current research in the Pacific and has commenced a summary file of scientific expeditions into the Pacific, particularly since 1900, in which the co-operation of scientific workers is invited. The secretariat has also initiated the formation of a Conservation Council for Hawaii and is seeking to establish an epidemiological information centre for the Pacific. It has also handled several specific inquiries from men of science and is issuing an Information Bulletin at six-weekly intervals, which is distributed free on request. 